\title{
Influence of Light Level on Performance of the Colorado Potato Beetle on Solanum tuberosum L. and on Resistance Expression in S. berthaultii Hawkes
}

\author{
Félix H. França ${ }^{1}$ and Ward M. Tingey \\ Department of Entomology, Tower Road Insectary, Cornell University, Ithaca, NY 14853-2604
}

\begin{abstract}
Additional index words. Coleoptera, Chrysomelidae, Leptinotarsa decemlineata, Solanaceae, potato, plant resistance, glandular trichomes, photosynthetically active radiation
\end{abstract}

\begin{abstract}
The influence of light level on the expression of resistance in Solanum berthaultii Hawkes (accessions PI 473331 and PI 473334) to the Colorado potato beetle (CPB), Leptinotarsa decemlineata (Say), was studied by exposing plants to two levels of photosynthetically active radiation: $272 \pm 37 \mu \mathrm{E} / \mathrm{m}^{2}$ per sec and $1025 \pm 150 \mu \mathrm{E} / \mathrm{m}^{2}$ per sec. Over 26 days, shading generally reduced densities of type $A$ and $B$ glandular trichomes, volume of trichome exudate, and phenolic oxidation activity of type A trichomes. In both light regimes, larvae reared on $S$. tuberosum L. were heavier, developed more rapidly, and had greater survival than those reared on $S$. berthaultii. Similarly, females reared on $S$. tuberosum were heavier and produced 10- to 20-fold more egg masses and 68 to 472 times more eggs than those reared on S. berthaultii grown at the same light level. Light level did not affect larval weight, developmental time, survival, adult weight, or fecundity of CPB on either host plant species.
\end{abstract}

The Colorado potato beetle (CPB), Leptinotarsa decemlineata, (Coleoptera: Chrysomelidae) has become the major limiting pest in potato production in the northeastern and mid-Atlantic regions of the United States during the past 20 years. Widespread resistance to nearly all registered insecticides (Forgash, 1981; Roush et al., 1990) and public concern over food and groundwater contamination have stimulated interest in alternative management methods such as plant resistance (Tingey, 1991).

Resistance to the CPB derived from the wild, tuber-bearing Bolivian potato species, Solanum berthaultii, is currently being used in several breeding programs (Plaisted et al., 1992). Solanum berthaultii foliage is characterized by two types of glandular trichomes that have been associated with the expression of insect resistance (Tingey, 1991). Although foliage of the cultivated insect-susceptible potato, $S$. tuberosum, bears type A trichomes morphologically indistinguishable from those of $S$. berthaultii, type A trichomes of the former do not function in insect resistance because they do not discharge their contents upon insect contact (Tingey, 1991).

Solanum berthaultii is a short-day species native to the highlands of the Andes and, in that environment, is subject to very high luminosity (Gibson, 1979) uncharacteristic of most temperate regions where potato is a major crop. Since light level has been reported to affect the expression of insect resistance in the wild potato $S$. chacoense Bitt. (Pierzchalski and Werner, 1958), the wild tomato Lycopersicon hirsutum f. glabratum C. H. Mull (Kennedy et al., 1981; Kennedy and Dimock, 1983), and other crops (Tingey and Singh, 1980), the present study was designed to examine the influence of light level on the interaction of CPB with $S$. berthaultii and $S$. tuberosum. The following questions were addressed. 1)

Received for publication 12 Nov. 1993. Accepted for publication 7 Feb. 1994. We thank J.C. Steffens for advice and consultation. F.H.F. wishes to express his appreciation to EMBRAPA-Empresa Brasileira de Pesquisa Agropecuária for the fellowship that supported this work. This research was also supported in part by the International Potato Center, grants from USDA-CSRS, and Hatch project NYC 139416. The cost of publishing this paper was defrayed in part by the payment of page charges. Under postal regulations, this paper therefore must be hereby marked advertisement solely to indicate this fact.

${ }^{1}$ Current address: EMBRAPA-C.N.P Hortaliças, Caixa Postal 07-0218, 70.359970 Brasilia DF, Brazil.
Does light level affect leaf area and glandular trichome characteristics of S. berthaultii and S. tuberosum? 2) Does light level affect performance of larval and adult CPBs? 3) Is resistance expression in $S$. berthaultii modified by shading?

\section{Materials and Methods}

General. These studies were carried out in the glasshouses and laboratory facilities of the Dept. of Entomology, Cornell Univ., Ithaca, N.Y., during Winters 1989 and 1990. The experimental glasshouse environment was maintained at $23 \pm 3 \mathrm{C}$ and $42 \% \pm 5 \%$ relative humidity $(\mathrm{RH})$. Insects were obtained from a colony maintained in a laboratory rearing room at $27 \pm 1 \mathrm{C}$ and $70 \% \pm 2 \%$ $\mathrm{RH}$. Soil moisture levels for all plants used in assays were recorded daily using an electrohygrometer (Labline, Chicago), and each test plant was irrigated when its soil moisture fell to $60 \%$.

Experimental design. A split-plot design (Little and Hills, 1978) was used in which two light levels were the main plots and host plant (S. tuberosum Katahdin and S. berthaultii PI 473331 and PI 473334) was the subplot. Subplots, each containing six host plants, were randomly placed within each of the two main plots. The experiment was repeated three times using new plants and insects for a total of three blocks (replications). Plants were acclimated to the light treatments for 10 days before the insects were caged.

Plant culture. 'Katahdin' plants were grown from certified seed tubers; those of $S$. berthaultii were grown from botanical seed provided by the U.S. Dept. of Agriculture Potato Introduction Station (Sturgeon Bay, Wis.). The S. berthaultii accession PI 473331 bears type A and B glandular trichomes, whereas PI 473334 has only type A trichomes. 'Katahdin' and S. berthaultii plants were used for these studies $\approx 44$ days after planting or transplanting, respectively. Bulk pollinated botanical seed of $S$. berthaultii produces a genetically heterogeneous plant population, even within the same accession. For this reason, plants selected for use in these studies were chosen for their phenotypic resemblance in plant architecture, leaf type, stem color, and flower color. Botanical seed was treated with gibberellic acid $\left(2 \mathrm{~g} \cdot \operatorname{liter}^{-1}, 24 \mathrm{~h}\right)$ to enhance germination; plant management practices were as described by França (1991). All plants were grown in a peat- 
vermiculite mixture containing encapsulated fertilizer [Osmocote (GTE Sylvania, Manchester, N.H.) 14N-14P-14K].

Light level. All plants were grown in a 16-h light-8-h dark photoperiod, and natural light was supplemented with metal halide illumination from Metalarc (Sierra Chemical Co., Milpitas, Calif.) lamps. Light level was determined by measuring photosynthetically active radiation (PAR) (400 to $700 \mathrm{~nm})$ at 12:00 PM using a quantum sensor (LI-190S; LI-COR, Lincoln, Neb.). These measurements were taken adjacent to a fully expanded mature leaf at the sixth node proximal to the apical node of the dominant mainstem. Shading was provided by a black polypropylene screen (Prop-a-lite, style 5186709; Chicopee Manufacturing Co., Cornellia, Ga.). Plants in the unshaded treatment were exposed to a PAR of $1025 \pm 150 \mu \mathrm{E} / \mathrm{m}^{2}$ per sec in contrast to $272 \pm 37 \mu \mathrm{E} / \mathrm{m}^{2}$ per sec in the shaded treatment.

Plant measurements. Leaf and leaflet area, trichome-specific phenolic oxidation activity (MEBA) (Avé et al., 1986; Ryan et al., 1982), glandular trichome density, and gland volume (Tingey and Sinden, 1982) were determined on days 10, 20, and 26 after study initiation using leaves from the sixth node proximal to the apical node. After excision, these leaves were transferred to test tubes filled with distilled water to prevent wilting and prepared for the MEBA assay (Avé et al., 1986; Ryan et al., 1982). Before MEBA assay initiation, a leaflet was removed, placed in a petri dish with moistened filter paper, and assessed for trichome characteristics (Tingey and Sinden, 1982). Trichomes from the center adaxial and abaxial surfaces were counted by microscopic examination at $\times 60$. Eyepieces equipped with grid and micrometer oculars were focused $2 \mathrm{~mm}$ from the side of the main vein, and all trichomes present in two opposing ocular quadrants $\left(2.25 \mathrm{~mm}^{2}\right)$ were counted; diameters of the apical trichome glands were determined using an ocular micrometer. Gland volume of individual trichomes was computed using the formula for the volume of a sphere $(\mathrm{V}=4.189$ $\mathrm{r}^{3}$ ). Data for trichome densities and gland volume were converted to $\mathrm{mm}^{2}$ before statistical analysis. Leaf and leaflet area were determined using a leaf area meter (LI-3000, LI-COR) equipped with a belt conveyer (LI-3005A, LI-COR).

Larval and pupal development. Egg masses were incubated at $27 \pm 1 \mathrm{C}$ and $70 \% \pm 2 \% \mathrm{RH}$. Cohorts of first instars were placed on test plants within $12 \mathrm{~h}$ of egg hatch. Larvae were confined on a leaf at the sixth node proximal to the apical node using cages constructed from cellulose dialysis tubing (VWR Scientific, Rochester, N.Y.) 14 to $17 \mathrm{~cm}$ long and $5 \mathrm{~cm}$ in diameter. Cages were gently placed around leaves to minimize disruption of the trichomes (Dimock et al., 1986). Larvae were placed on the leaves using a camel hair paint brush (no. 00; Grumbacher 178, Ireland) in cohorts of 5 or 10 each, depending on leaf size and availability. After foliage was depleted by feeding, the cage and larvae were moved to a leaf at an adjacent node. In most cases, one fully mature leaf was sufficient to maintain a cohort of 5 to 10 larvae until the pupal stage.

Fourth instars were closely monitored; development was considered complete when $50 \%$ of the surviving larvae in each cage displayed at least two of the following characteristics: 1) cessation of feeding, 2) color changed from brown or red to orange-yellow, or 3 ) restlessness. Larvae were removed from the cages, weighed to the nearest milligram using an electrobalance (model 28; Cahn Instruments, Cerritos, Calif.), and placed in 500-ml clear plastic containers (16S DP-SQUAT deli container, Fabri-Kal Corp., Kalamazoo, Mich.) half filled with moistened peat-vermiculite medium. Excised foliage was placed in the containers to ensure that slightly immature larvae would have adequate food to mature. Adults were sexed within $12 \mathrm{~h}$ of emergence and weighed to the nearest mg. Preadult development time was determined by the number of days between the time the newly hatched larvae were caged on their host and the time $50 \%$ of adults emerged. Survival at the fourth larval instar and at adult emergence was computed as a proportion of surviving individuals to the number of first instars used to initiate the experiment.

Reproductive performance. Two pairs of adults obtained from the laboratory colony were confined to the upper one-third of each of six plants of 'Katahdin', PI 473331, and PI 473334 for 21 days using $18 \times 28-\mathrm{cm}$ white polyester sleeve cages (No See Um; Balson-Hercules Group, Providence, R.I.). Females and males were weighed before caging and also at the end of the experiment. Cages were examined at 2-day intervals, egg masses were removed, and the number of eggs in each egg mass was determined.

Statistical analysis. Data were analyzed using the GLM procedure for analysis of variance (SAS Institute, 1985). Data for leaf and leaflet area, trichome-specific phenolic oxidation activity, glandular trichome density, and gland volume obtained 10,20, and 26 days after study initiation were averaged over the three sample dates before statistical analysis. An arcsin transformation was performed on survival data; total egg production and number of egg masses per female were transformed to $\log x+10$ before analysis to meet the assumption that variances and means of different samples were independent (Little and Hills, 1978). Subplot means (host plants) within the main plots (light levels) were examined by Fisher's protected LSD (Little and Hills, 1978). The $t$ test procedure (SAS Institute, 1985) was used to compare light levels within each host.

\section{Results}

Light level did not affect leaf or leaflet area (Table 1). The $S$. berthaultii accessions did not differ in leaf area. 'Katahdin' leaf area did not differ from that of PI 473331 but was $\approx 45 \%$ greater than that of PI $473334(P<0.01)$. 'Katahdin' leaflet area was about twice that of $S$. berthaultii $(P<0.01)$.

Browning activity of PI 473331 foliage was reduced in the shaded environment, whereas that of PI 473334 was not affected (Table 1). Browning activity of $S$. berthaultii foliage was greater than that of S. tuberosum; PI 473331 and PI 473334 had similar levels of browning activity.

Shading produced a $36 \%(P<0.01)$ and $45 \%(P<0.01)$ reduction in abaxial densities of type A trichomes on PI 473331 and PI 473334, respectively (Table 1). 'Katahdin' abaxial trichome density was not affected by light level. Adaxial densities of type A trichomes in the shaded environment were reduced $40 \%$ ( $P$ $<0.01$ ) on PI 473334; light level did not affect adaxial density of type A trichomes on PI 473331.

Shading produced a $36 \%(P<0.05)$ decrease in gland volume per square millimeter of type A trichomes on PI 473331, whereas gland volume of PI 473334 trichomes was unaffected by light level (Table 1).

Shading produced a $35 \%$ reduction in densities of abaxial $(P<$ $0.01)$ and adaxial $(P<0.01)$ type B trichomes on PI 473331 and a $44 \%(P<0.05)$ reduction in volume of type B exudate per square millimeter (Table 1).

Light level did not significantly affect larval or adult weight, larval survival, or development time for any of the cohorts reared as larvae on the three hosts (Table 2). Fourth instar larvae reared on 'Katahdin' were significantly heavier than those reared on $S$. berthaultii; i.e., 3-fold heavier than those on PI 473331 and $\approx 2$-fold heavier than those than PI 473334 (Table 2). Females reared on 'Katahdin' were $20 \%$ to $29 \%$ heavier than those reared on $S$. 
Table 1. Influence of two levels of light on leaf and leaflet area, browning activity, and glandular trichome characteristics of Solanum tuberosum 'Katahdin', and S. berthaultii accessions PI 473331 and PI 473334. Data are pooled averages of measurements taken at 10, 20, and 26 days.

\begin{tabular}{|c|c|c|c|c|c|c|}
\hline \multirow[b]{2}{*}{ Host } & \multicolumn{2}{|c|}{ Leaf area $\left(\mathrm{cm}^{2}\right)^{\mathrm{z}}$} & \multicolumn{2}{|c|}{ Leaflet area $\left(\mathrm{cm}^{2}\right)^{\mathrm{z}}$} & \multicolumn{2}{|c|}{$\begin{array}{c}\text { Browning activity } \\
(\% \text { transmission at } 470 \mathrm{~nm})\end{array}$} \\
\hline & Light & Shade & Light & Shade & Light & Shade \\
\hline Katahdin & $80 \pm 6 \mathrm{aA}^{\mathrm{y}}$ & $68 \pm 7 \mathrm{aA}$ & $13 \pm 1 \mathrm{aA}$ & $12 \pm 1 \mathrm{aA}$ & $94 \pm 1 \mathrm{aA}$ & $96 \pm 1 \mathrm{aA}$ \\
\hline PI 473331 & $59 \pm 8 \mathrm{abA}$ & $48 \pm 8 \mathrm{aA}$ & $6 \pm 1 \mathrm{bA}$ & $6 \pm 1 \mathrm{bA}$ & $39 \pm 3 \mathrm{bA}$ & $48 \pm 3 \mathrm{bB}$ \\
\hline PI 473334 & $44 \pm 8 \mathrm{bA}$ & $47 \pm 8 \mathrm{aA}$ & $6 \pm 1 \mathrm{bA}$ & $6 \pm 1 \mathrm{bA}$ & $47 \pm 3 \mathrm{bA}$ & $53 \pm 2 \mathrm{bA}$ \\
\hline \multirow[t]{4}{*}{$\operatorname{LSD}(P=0.05)$} & \multirow{2}{*}{\multicolumn{2}{|c|}{30}} & \multicolumn{2}{|c|}{4} & \multirow{2}{*}{\multicolumn{2}{|c|}{9}} \\
\hline & & & \multicolumn{2}{|c|}{ Type A trichomes } & & \\
\hline & \multicolumn{2}{|c|}{ Abaxial (no. $\left./ \mathrm{mm}^{2}\right)$} & \multicolumn{2}{|c|}{ Adaxial $\left(\mathrm{no} . / \mathrm{mm}^{2}\right)$} & \multicolumn{2}{|c|}{ Volume $/ \mathrm{mm}^{2}\left(\mathrm{~mm}^{3} \times 10^{-5}\right)$} \\
\hline & Light & Shade & Light & Shade & Light & Shade \\
\hline Katahdin & $3 \pm 1 \mathrm{aA}$ & $2 \pm 0 \mathrm{aA}$ & $0 \mathrm{aA}$ & $0 \mathrm{aA}$ & $23 \pm 5 \mathrm{aA}$ & $13 \pm 3 \mathrm{aA}$ \\
\hline PI 473331 & $11 \pm 1 \mathrm{bA}$ & $7 \pm 1 \mathrm{bB}$ & $12 \pm 1 \mathrm{bA}$ & $10 \pm 1 \mathrm{bA}$ & $256 \pm 29 \mathrm{bA}$ & $165 \pm 19 \mathrm{bB}$ \\
\hline PI 473334 & $11 \pm 2 \mathrm{bA}$ & $6 \pm 1 \mathrm{abB}$ & $15 \pm 2 \mathrm{bA}$ & $9 \pm 1 \mathrm{bB}$ & $203 \pm 23 b A$ & $156 \pm 18 \mathrm{bA}$ \\
\hline \multirow[t]{2}{*}{$\operatorname{LSD}(P=0.05)$} & \multirow{2}{*}{\multicolumn{2}{|c|}{4}} & \multicolumn{2}{|c|}{4} & \multicolumn{2}{|c|}{75} \\
\hline & & & \multicolumn{2}{|c|}{ Type B trichomes } & & \\
\hline PI 473331 & $17 \pm 1 \mathrm{~A}$ & $11 \pm 1 \mathrm{~B}$ & $14 \pm 1 \mathrm{~A}$ & $9 \pm 1 B$ & $27 \pm 4 \mathrm{~A}$ & $15 \pm 2 \mathrm{~B}$ \\
\hline
\end{tabular}

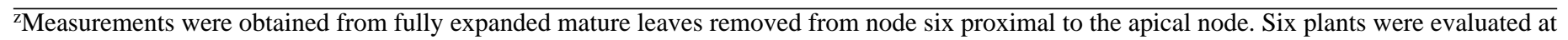
day 10 and three plants were evaluated on days 20 and 26 for each host in each light level.

'In each column, means ( \pm SE of the mean) followed by the same lower-case letter are not significantly different $(P \leq 0.05$; Fisher's protected LSD). In each row, within the same parameter of evaluation, means followed by the same capital letter are not significantly different $(P \leq 0.05, t$ test $)$. The absence of lower-case letters indicates that differences are not statistically significant (analysis of variance; $P>0.05$ ).

Table 2. Weight, survival, and development time of the Colorado potato beetle reared as larvae on Solanum tuberosum 'Katahdin' and S. berthaultii accessions PI 473331 and PI 473334 and exposed to two light levels.

\begin{tabular}{|c|c|c|c|c|c|c|}
\hline \multirow[b]{2}{*}{ Host } & \multicolumn{2}{|c|}{ Fourth instar } & \multicolumn{2}{|c|}{ Female } & \multicolumn{2}{|c|}{ Male } \\
\hline & Light & Shade & Light & Shade & Light & Shade \\
\hline & \multicolumn{6}{|c|}{$W t(m g)$} \\
\hline Katahdin & $120 \pm 21 \mathrm{aA}^{\mathrm{z}}$ & $90 \pm 26 \mathrm{aA}$ & $137 \pm 6 \mathrm{aA}$ & $126 \pm 12 \mathrm{aA}$ & $107 \pm 3 \mathrm{~A}$ & $103 \pm 5 \mathrm{~A}$ \\
\hline PI 473331 & $39 \pm 14 \mathrm{bA}$ & $29 \pm 7 \mathrm{bA}$ & $97 \pm 10 \mathrm{bA}$ & $106 \pm 7 \mathrm{aA}$ & $99 \pm 7 \mathrm{~A}$ & $82 \pm 14 \mathrm{~A}$ \\
\hline \multirow[t]{3}{*}{ PI 473334} & $69 \pm 26 \mathrm{bA}$ & $56 \pm 19 \mathrm{abA}$ & $123 \pm 3 \mathrm{abA}$ & $115 \pm 9 \mathrm{aA}$ & $104 \pm 3 \mathrm{~A}$ & $92 \pm 8 \mathrm{~A}$ \\
\hline & \multirow{2}{*}{\multicolumn{2}{|c|}{$\begin{array}{l}\text { Fourth instar } \\
\text { survival (\%) }\end{array}$}} & \multicolumn{4}{|c|}{ Preadult } \\
\hline & & & Cumulati & vival (\%) & Develop & e (days) \\
\hline Katahdin & $79 \pm 2 \mathrm{aA}$ & $66 \pm 1 \mathrm{aA}$ & $51 \pm 1 \mathrm{aA}$ & $46 \pm 1 \mathrm{aA}$ & $23 \pm 1 \mathrm{aA}$ & $22 \pm 1 \mathrm{aA}$ \\
\hline PI 473331 & $32 \pm 1 \mathrm{bA}$ & $35 \pm 4 \mathrm{bA}$ & $21 \pm 1 \mathrm{bA}$ & $10 \pm 2 \mathrm{bA}$ & $27 \pm 1 \mathrm{cA}$ & $27 \pm 1 \mathrm{cA}$ \\
\hline PI 473334 & $58 \pm 3 \mathrm{abA}$ & $64 \pm 3 \mathrm{aA}$ & $31 \pm 2 \mathrm{abA}$ & $21 \pm 1 \mathrm{abA}$ & $24 \pm 1 \mathrm{bA}$ & $24 \pm 1 \mathrm{bA}$ \\
\hline
\end{tabular}

${ }^{\mathrm{Z}}$ In each column, means ( \pm SE of the mean) followed by the same lower-case letter are not significantly different $(P \leq 0.05 ;$ Fisher's protected LSD). In each row, within the same parameter of evaluation, means followed by the same capital letter are not significantly different $(P \leq 0.05, t$ test $)$. The absence of lower-case letters indicates that differences are not statistically significant (analysis of variance; $P>0.05$ ).

berthaultii $(P<0.05)$. Male weight did not differ on the three hosts.

When confined on each of the hosts as adults for 21 days, females on $S$. berthaultii were significantly lighter than their initial weights in both light regimes (Table 3). Female weight on 'Katahdin' after 21 days of confinement did not differ from that recorded at the beginning of the study.

Larval survival on 'Katahdin' was about twice that on PI 473331. Under shade, larval survival on PI 473334 was $\approx 2$-fold greater than on PI 473331 (Table 2). Preadult survival was significantly greater on 'Katahdin' than on PI 473331, but it did not differ from that on PI 473334.

Preadult development time on 'Katahdin' was shorter than that on $S$. berthaultii $(P<0.01)$. Development time on PI 473331 was delayed 3 days compared to PI 473334 and 4 days compared to 'Katahdin' (Table 2).

Light level did not significantly affect reproductive performance for any of the three hosts (Table 4). Females laid 10- to 20- fold more egg masses and produced 68- to 472-fold more eggs on 'Katahdin' than on PI 473331 and PI $473334(P<0.01)$.

\section{Discussion}

The PAR available to plants in the unshaded environment (1025 $\pm 150 \mu \mathrm{E} / \mathrm{m}^{2}$ per sec) was equivalent to one-half that of sunlight. The photosynthetic rate of potato leaves responds to light asymptotically and saturation is achieved at an irradiance of $\approx 850 \mu \mathrm{E} / \mathrm{m}^{2}$ per sec; further increases in light level do not increase photosynthetic rate (Ku et al., 1977). Full sunlight plus sky PAR provide $\approx 2000 \mu \mathrm{E} / \mathrm{m}^{2}$ per sec. Consequently, plants in the shaded environment had $\approx 32 \%\left(272 \pm 37 \mu \mathrm{E} / \mathrm{m}^{2}\right.$ per sec $)$ of the PAR necessary for saturation.

Reduced light level produced an unusual growth response in $S$. berthaultii plants. After 5 days in the shaded environment, edges of leaflets located in the middle of the plant were curled upward, 
Table 3. Weight (mg) of Colorado potato beetles confined as adults on Solanum tuberosum 'Katahdin' and S. berthaultii PI 473331 and PI 473334 for 21 days at two light levels.

\begin{tabular}{lccccc}
\hline & \multicolumn{2}{c}{ Female } & & \multicolumn{2}{c}{ Male } \\
\cline { 2 - 3 } \cline { 5 - 6 } Host & Light & Shade & & Light & Shade \\
\hline Katahdin & $160 \pm 13 \mathrm{aA}^{z}$ & $161 \pm 11 \mathrm{aA}$ & & $108 \pm 3 \mathrm{~A}$ & $121 \pm 6 \mathrm{~A}$ \\
PI 473331 & $115 \pm 10 \mathrm{bA}^{*}$ & $115 \pm 15 \mathrm{bA}^{*}$ & & $109 \pm 14 \mathrm{~A}$ & $114 \pm 9 \mathrm{~A}$ \\
PI 473334 & $128 \pm 9 \mathrm{abA}^{*}$ & $144 \pm 5 \mathrm{abA}^{*}$ & & $101 \pm 7 \mathrm{~A}$ & $110 \pm 17 \mathrm{~A}$
\end{tabular}

\begin{abstract}
${ }^{\mathrm{z}}$ In each column, means ( \pm SE of the mean) followed by the same lower-case letter are not significantly different ( $P \leq 0.05$; Fisher's protected LSD). In each row, within the same parameter of evaluation, means followed by the same capital letter are not significantly different $(P \leq 0.05, t$ test).

*Significantly less $(P \leq 0.05, t$ test $)$ than mean initial weight $(186 \pm 6 \mathrm{mg})$ recorded immediately before caging.
\end{abstract}

whereas the petioles of leaves on the lower one-third of the plant were twisted almost $180^{\circ}$, exposing nearly all of the abaxial leaf surface to the light source. This may have been a response to maximize absorption of light for photosynthesis (Salisbury and Ross, 1978), given that $S$. berthaultii evolved in high Andean environments characterized by high luminosity. We did not observe this phenomenon in light-deprived $S$. tuberosum plants.

Shading did not increase leaf and leaflet area, a result that is surprising given that the generalized leaf response to reduced light level is an increase in leaf area (Salisbury and Ross, 1978). However, we sampled leaves from the upper one-third of the plant and, even in the reduced-light regime, these leaves may have had PAR within the range needed for normal growth (Ku et al., 1977).

With increasing leaf expansion, a corresponding decrease in trichome density would be expected because the number of trichomes is thought to be determined early in leaf development (Unzelman and Healey, 1974). However, leaf and leaflet area were not affected by shade, a result suggesting that the observed reduction in trichome density and decrease in trichome exudate production has a physiological basis and is not simply the result of leaf expansion or cell enlargement. Possible explanations for this phenomenon include 1) plants allocated more energy to stem growth than to the leaves at the expense of trichomes and 2) leaves under shade invest large amounts of energy in producing chlorophyll pigments to maximize light absorption (Salisbury and Ross, 1978), possibly at the expense of the energy required by the epithelial cells to produce new trichomes (Unzelman and Healey, 1974) or at the expense of the energy requirements to produce exudate (Steffens and Walters, 1991).

Solanum berthaultii glandular trichomes defend plants against CPBs 1) as a physical barrier against small larvae (Dimock and Tingey, 1988) and 2) by the presence of type A and B trichomes, which reduces the acceptability of the plant, thus conditioning avoidance behavior (Dimock and Tingey, 1988; Neal et al., 1989). Type B droplets containing acyl sugars and type A trichomes expressing high levels of phenolic oxidation activity (Kowalski et al., 1990) are complementary (although the mechanism is not known) in resistance expression against first instar larvae (Neal et al., 1989). The physiological target sites in CPBs affected by sucrose sugars and phenolic oxidation products are also unknown.

Although reduced fecundity is a consistent response of CPBs to S. berthaultii (Casagrande, 1982; Dimock and Tingey, 1985), it is not known to what extent this process is influenced by physiological and behavioral mechanisms. The dramatic decrease in female weight on S. berthaultii (PI 473331) that we observed at the end of the 21-day oviposition confinement period suggests the possibility
Table 4. Fecundity and egg mass production ${ }^{\mathrm{z}}$ by Colorado potato beetles confined as adults on Solanum tuberosum 'Katahdin' and S. berthaultii accessions PI 473331 and PI 473334 for 21 days and exposed to two light levels.

\begin{tabular}{lrrrrr}
\hline \hline & \multicolumn{2}{c}{ Fecundity } & & \multicolumn{2}{c}{ No. egg masses } \\
\cline { 2 - 3 } \cline { 5 - 6 } Host & \multicolumn{1}{c}{ Light } & Shade & & Light & Shade \\
\hline Katahdin & $472 \mathrm{aA}^{\mathrm{z}}$ & $406 \mathrm{aA}$ & & $20 \mathrm{aA}$ & $19 \mathrm{aA}$ \\
PI 473331 & $5 \mathrm{bA}$ & $6 \mathrm{bA}$ & & $2 \mathrm{bA}$ & $2 \mathrm{bA}$ \\
PI 473334 & $1 \mathrm{bA}$ & $1 \mathrm{bA}$ & & $1 \mathrm{bA}$ & $1 \mathrm{bA}$ \\
\hline
\end{tabular}

${ }_{\mathrm{z}}$ Mean number of eggs and number of egg masses produced per female during 21 days, back-transformed from $\log (\mathrm{x}+0.5)$.

y In each column, means followed by the same lower-case letter are not significantly different ( $P \leq 0.05$; Fisher's protected LSD). In each row, within the same parameter of evaluation, means followed by the same capital letter are not different $(P \leq 0.05, t$ test).

of retarded ovary development resulting from reduced food intake (Pelletier and Smilowitz, 1990) or, alternatively, imperfect nutritional quality of $S$. berthaultii foliage.

Despite shade-induced reductions in browning activity, density, and volume of type A and B trichomes on S. berthaultii PI 473331, resistance expression as measured by larval and reproductive performance was comparable to that on plants that were not deprived of light. This suggests that, although densities and gland volume of type A and B trichomes were reduced, they were above threshold levels necessary to provide a high degree of resistance. Alternatively, biologically active compounds in glandular trichome exudate other than acyl sugars and phenolic oxidation products may be important in resistance expression. There is strong evidence to support the first hypothesis (Neal et al., 1989) and the second is currently being examined.

In summary, $S$. berthaultii resistance was remarkably stable despite shading, which dramatically altered plant growth habit and significantly reduced trichome density, gland volume, and trichome phenolic oxidation activity. This finding, coupled with that of Pelletier (1990) that trichome density was not affected by water stress and that mortality of larvae on S. berthaultii was not affected by soil moisture levels, suggests that resistance derived from $S$. berthaultii should be stable across a range of environments and that breeding programs can somewhat relax selection for trichome density and exudate production in clones having highly desirable horticultural characteristics without sacrificing useful resistance levels.

\section{Literature Cited}

Avé, D.A., N.T. Eannetta, and W.M. Tingey. 1986. A modified enzymic browning assay for potato glandular trichomes. Amer. Potato J. 63:553558.

Casagrande, R.A. 1982 Colorado potato beetle resistance in a wild potato, Solanum berthaultii. J. Econ. Entomol. 75:368-372.

Dimock, M.B. and W.M. Tingey. 1985. Resistance in Solanum species to the Colorado potato beetle: Mechanisms, genetic resources, and potential, p. 79-106. In: D.N. Ferro and R.H. Voss (eds.). Proc. Symp. Colorado potato beetle, XVIIth Intl. Congr. Entomol. Mass. Agr. Expt. Sta. Bul. 704.

Dimock, M.B. and W.M. Tingey. 1988. Host acceptance behaviour of Colorado potato beetle larvae influenced by potato glandular trichomes. Physiol. Entomol. 13:399-406.

Dimock, M.B., S.L. Lapointe, and W.M. Tingey. 1986. Solanum neocardenasii: A new source of potato resistance to the Colorado potato beetle (Coleoptera: Chrysomelidae). J. Econ. Entomol. 79:1269-1275. Forgash, A.J. 1981. Insecticide resistance of the Colorado potato beetle, Leptinotarsa decemlineata (Say), p. 34-46. In: J.H. Lashomb and R. 
Casagrande (eds.). Advances in potato pest management. Hutchinson Ross Publishing Co., Stroudsburg, Pa.

França, Felix H. 1991. Stability and aspects of resistance of Solanum berthaultii Hawkes to populations of the Colorado potato beetle, Leptinotarsa decemlineata (Say) (Coleoptera: Chrysomelidae). PhD diss. Cornell Univ., Ithaca, N.Y.

Gibson, R.W. 1979. The geographical distribution, inheritance and pestresisting properties of sticky-tipped foliar hairs on potato species. Potato Res. 22:223-236.

Kennedy, G.G. and M.B. Dimock. 1983. 2-Tridecanone: A natural toxicant in a wild tomato responsible for insect resistance, p. 123-128. In: J. Miyamoto (ed.). IUPAC pesticide chemistry: Human welfare and the environment. Pergamon Press, New York.

Kennedy, G.G., R.T. Yamamoto, M.B. Dimock, W.G. Williams, and J. Bordner. 1981. Effect of day length and light intensity on 2-tridecanone levels and resistance in Lycopersicon hirsutum f. glabratum to Manduca sexta. J. Chem. Ecol. 7:707-716.

Kowalski, S.P., J.B. Bamberg, W.M. Tingey, and J.C. Steffens. 1990. Inheritance of polyphenol oxidase in type A glandular trichomes of Solanum berthaultii. J. Hered. 81:475-478.

Ku, S.B., G.E. Edwards, and C.B. Tanner. 1977. Effects of light, carbon dioxide, and temperature on photosynthesis, oxygen inhibition of photosynthesis, and transpiration in Solanum tuberosum. Plant Physiol. 59:868-872.

Little, T. M. and F. J. Hills. 1978. Agricultural experimentation: Design and analysis. Wiley, New York.

Neal, J.J., J.C. Steffens, and W.M. Tingey. 1989. Glandular trichomes of Solanum berthaultii and resistance to the Colorado potato beetle. Entomol. Expt. Applications 51:133-140.

Pelletier, Y. 1990. The effect of water stress and leaflet size on the density of trichomes and the resistance to Colorado potato beetle larvae (Leptinotarsa decemlineata Say) in Solanum berthaultii Hawkes. Can. Entomol. 122:1141-1147.

Pelletier, Y. and Z. Smilowitz 1990. Effect of trichome B exudate of Solanum berthaultii Hawkes on its consumption by the Colorado potato beetle, Leptinotarsa decemlineata (Say). J. Chem. Ecol. 16:1547-1555.

Pierzchalski T. and E. Werner. 1958. Changes in glycoalkaloid content in leaves of cultivated and wild potatoes and their hybrids during growth and their influence on the Colorado potato beetle (Leptinotarsa decemlineata Say). Part I. Hodowla Roslin Aklimatyzacja I Nasiennictwo. vol. 2. p. 157-180. (Translated from Polish, NSF-USDA, 1964.)

Plaisted, R.L., W.M. Tingey, and J.C. Steffens. 1992. The germplasm release of NYL 235-4, a clone with resistance to the Colorado potato beetle. Amer. Potato J. 69:843-846.

Roush, R.T., C.W. Hoy, D.N. Ferro, and W.M. Tingey. 1990. Insecticide resistance in the Colorado potato beetle (Coleoptera: Chrysomelidae): Influence of crop rotation and insecticide use. J. Econ. Entomol. 83:315-319.

Ryan, J.D., P. Gregory, and W.M. Tingey. 1982. Glandular trichomes: Enzymic browning assay for improved selection of resistance to the green peach aphid. Amer. Potato J. 60: 861-868.

Salisbury, F.B. and C.W. Ross. 1978. Plant physiology. Wadsworth Publishing Co., Belmont, Calif.

SAS Institute. 1985. SAS user's guide: Statistics. SAS Inst., Cary, N.C. Steffens, J.C. and D. Walters. 1991. Biochemical aspects of glandular trichome-mediated resistance in the Solanaceae, p. 136-149. In: P.A. Hedin (ed.). Naturally occurring pest bioregulators. ACS, Washington, D.C., Symp. Ser. 449.

Tingey, W.M. 1991. Potato glandular trichomes-Defensive activity against insect attack, p. 126-135. In: P.A. Hedin (ed.). Naturally occurring pest bioregulators. ACS, Washington, D.C., Symp. Ser. 449. Tingey, W.M. and S.L. Sinden. 1982. Glandular pubescence, glycoalkaloid composition, and resistance to the green peach aphid, potato leafhopper, and potato fleabeetle in Solanum berthaultii. Amer. Potato J. 59:95-106.

Tingey, W.M. and S.R. Singh. 1980. Environmental factors influencing the magnitude and expression of resistance, p. 89-113. In: F.G. Maxwell and P.R. Jennings (eds.). Breeding plants resistant to insects. Wiley, New York.

Unzelman, J.M and P.L. Healey. 1974. Development, structure, and occurrence of secretory trichomes of Pharbitis. Protoplasma 80:285303. 